\title{
Translation and Cross-Cultural Adaptation of a Brazilian Version of the Child Feeding Questionnaire ${ }^{1}$
}

\author{
Luciana Lorenzato \\ Universidade de São Paulo, \\ Ribeirão Preto-SP, Brazil
}

\author{
Isadora Silva Miranda Cruz \\ Universidade de São Paulo, \\ Ribeirão Preto-SP, Brazil
}

\author{
Telma Maria Braga Costa \\ Universidade de Ribeirão \\ Preto, Ribeirão Preto-SP, Brazil
}

\author{
Sebastião Sousa Almeida ${ }^{2}$ \\ Universidade de São Paulo, \\ Ribeirão Preto-SP, Brazil
}

\begin{abstract}
The Child Feeding Questionnaire (CFQ) assesses parental attitudes, beliefs and practices about child feeding and obesity proneness. This research aimed to translate and to test the reliability of the CFQ and to evaluate this instrument in Brazilian families. The participants were 300 mothers and 300 children, aging from 2 to 11 years old, of both sexes. The translation, synthesis, back-translation, evaluation by an expert committee and pre-test were performed. Besides the application of questionnaire to mothers, data regarding anthropometric measurements in mothers and children was collected. The indexes of content validity index, test-retest reliability and internal consistencies were good. The parental factors Perceived parent weight, Perceived child weight, Concern about child weight, Restriction, Pressure to eat and Monitoring on child feeding were associated with overweight in childhood. In conclusion, these results highlight the validity and utility of the Brazilian version of the CFQ.
\end{abstract}

Keywords: eating, eating behavior, obesity in children, questionnaire, translating

\section{Tradução e Adaptação Transcultural da Versão Brasileira do Questionário de Alimentação da Criança}

\begin{abstract}
Resumo: O Questionário de Alimentação da Criança (QAC) avalia as crenças, atitudes e práticas dos pais em relação a alimentação e a propensão à obesidade dos filhos. Este estudo objetivou traduzir e testar a fidedignidade do QAC e avaliar este instrumento em famílias brasileiras. Os participantes foram 300 mães e 300 crianças, de 2 a 11 anos, de ambos os sexos. Realizou-se a tradução, síntese, retrotradução, avaliação por comitê de especialistas e pré-teste. Para além da aplicação do questionário às mães, foram também recolhidos dados realtivos à avaliação antropométrica das mães e filhos. Os índices de validade de conteúdo, confiabilidade teste-reteste e consistência interna foram adequados. Os fatores Percepção do peso dos pais, Percepção do peso da criança, Preocupação com o peso da criança, Restrição, Pressão para comer e Monitoramento mostraram-se associados com a obesidade infantil. Em conclusão, esses resultados destacam a validade e a utilidade da versão brasileira do CFQ.
\end{abstract}

Palavras-chave: alimentação, comportamento alimentar, obesidade infantil, questionário, tradução

\section{Traducción y Adaptación Cultural de la Versión Brasileña del Cuestionario de la Alimentación del Niño}

\begin{abstract}
Resumen: El Cuestionario de Alimentación Infantil (acrónimo en inglés CFQ) evalúa las creencias, actitudes y prácticas de los padres con relación al poder y la propensión a la obesidad de los niños. Este estudio tuvo como objetivo traducir y poner a prueba la fiabilidad del CFQ y evaluar este instrumento en las familias brasileñas. Los participantes fueron 300 madres y 300 niños, 2-11 años, de ambos géneros. La traducción, síntesis, retro traducción, evaluación por el comité de expertos y pre-test se llevaron a cabo. Además de la aplicación del cuestionario, también fueron recolectados datos relativos a la evaluación antropométrica de las madres y los niños. Los índices de validez de contenido, fiabilidad test-retest y consistencia interna fueron adecuados. Los factores Percepción del peso de los padrea, Percepción del peso del hijo, Preocupación con el peso del niño, Restricción, Presión para comer y Monitoreo estaban asociados con la obesidad infantil. En conclusión, estos resultados ponen de manifiesto la validez y utilidad de la versión brasileña del CFQ.
\end{abstract}

Palabras clave: alimentación, comportamiento de alimentación, obesidad infantil, cuestionario, traducción

\footnotetext{
${ }^{1}$ Article derived from master's thesis of the first and second authors under supervision of the fourth author, defended in 2009 and 2012 respectively, in the Graduate Program in Psychobiology and Psychology at Faculdade de Filosofia, Ciências e Letras of Ribeirão Preto of the Universidade de São Paulo. Support: Coordination for the Improvement of Higher Education Personnel (CAPES).
}

${ }^{2}$ Correspondence address:

Universidade de São Paulo, Faculdade de Filosofia, Ciências e Letras de Ribeirão Preto, Departamento de Psicologia, Laboratório de Nutrição e Comportamento. Av. Bandeirantes, 3900, Vila Monte Alegre. CEP 14040901. Ribeirão Preto-SP, Brasil. E-mail: sebasalm@usp.br 
Childhood obesity is considered a public health problem, with prevalence rates progressively increasing. It determines various health complications during childhood and adulthood, as cardiovascular disease, dyslipidemia, hypertension, muscle problems, joint, skeletal and circulatory, liver and lung complications, type 2 diabetes and cancer (Popkin, Adair, \& Ng, 2012). In Brazil, the latest data collection by the POF (Portuguese abbreviation of Pesquisa de Orçamentos Familiares) in 2008-2009 showed that the prevalence of overweight and obesity, on children above 5 years old, increased in all regions and in all strata of income (Instituto Brasileiro de Geografia e Estatística [IBGE], 2010).

Obesity has a multifactorial etiology, being the result of complex interactions between genetic, dietary and environmental factors (Quaioti \& Almeida, 2006). However, the rapid increase in its prevalence highlights the importance of the environment and the need of research able to outline the environmental factors involved in childhood obesity etiology. Among the environmental factors, diet, physical activity, family influence, socioeconomic and cultural environment are considered responsible for the increased incidence of obesity in childhood and adolescence (Giskes, van Lenthe, Avendano-Pabon, \& Brug, 2010; Scaglioni, Arrizza, Vecchi, $\&$ Tedeschi, 2011).

In this sense, it emphasizes the central role of the family in shaping the eating behavior in childhood and the influence of parental attitudes, beliefs and practices about child feeding in the obesity proneness during infancy. However, in Brazil there are not any validated instruments to assess these factors associated with childhood obesity. The Child Feeding Questionnaire (CFQ) was proposed to assess parental perceptions and concerns regarding child obesity, as well as child feeding attitudes and practices. This questionnaire is appropriate to be used in research with parents of normally developing children ranging from preschool age through middle childhood (children aging from 2 to 11 years old; Birch et al., 2001).

Preliminary investigations were carried out in a threestage version of the questionnaire in order to develop the CFQ. The first version of the CFQ was evaluated by Johnson and Birch (1994) in a sample of 77 families of preschoolaged children. This version consisted on a questionnaire of 24 forced-choice items adapted from Costanzo and Woody (1985) to measure parental attitudes, beliefs and strain of control in feeding. It included items tapping parental concerns about child weight status, as well as items that assessed parental feeding practices and the energy intake balance in the child feeding relationship. Early results indicated links between parental controlling attitudes and practices and children's eating; parents who reported higher control levels over child feeding had children less adjusted to their intake in response to differences in food caloric density. Moreover, they observed that parents of heavier children reported using higher control levels in the feeding context. In a second stage of development, some items were revised and an exploratory factor analysis was conducted on a sample of 275 families with similar aged children previously adopted. As in previous research, exploratory analyses revealed a factor measuring parental control in child feeding, thus identifying the following factors: parental concern about child weight, perceived child weight, and perceived parent weight. Items regarding parents' perceived responsibility for child-feeding tasks were added in the last stage of development in order to facilitate an understanding of factors that might elicit parental use of control in child feeding. Regarding specific parental control in feeding, previous research revealed that parents tended to use two distinct types of control, pressuring children to eat and restricting their access to snack foods, which were intended to address different problems with children's eating. As a result, items tapping parental use of restriction and the pressure to eat with their children were added to the CFQ. A third set of items designed to tap parental monitoring was also added (Birch et al., 2001).

The current version of the CFQ contains items which measure seven different dimensions, including four factors tapping parental perceptions and concerns that may prompt the use of controlling child-feeding practices: perceived parent weight, perceived child weight, parental concern about child weight, and parental responsibility. The other three factors assessed parental control attitudes and practices in child feeding, including the use of restriction, pressuring children to eat more and monitoring (Birch et al., 2001).

The English version of the original CFQ by Birch et al. (2001) has been translated into many contexts: Portuguese of Portugal by Viana et al. (2012), Turkish by Camci, Bas, and Buyukkaragoz (2014), Australian by Corsini, Danthiir, Kettler, and Wilson (2008), Japanese by Geng et al. (2009), French by Monnery-Patris et al. (2011) and Swedish by Nowicka, Sorjonen, Pietrobelli, Flodmark, and Faith (2014). All these versions show good factorial validity, reporting a stable factor solution for the total CFQ and for the seven subscales, reliability and also satisfactory internal consistency. The CFQ has been widely used in recent international studies, which have proved it an efficient instrument, however to date, no version adapted for Brazil has been developed (Carnell \& Wardle, 2007; Huang et al., 2012; Kasemsup \& Reicks, 2006; Kong, Vijayasiri, Fitzgibbon, Schiffer, \& Campbell, 2015; Monnery-Patris et al., 2011; Montgomery, Jackson, Kelly, \& Reilly, 2006; Mulder, Kain, Uauy, \& Seidell, 2009; O’Neill, Shults, Stallings, \& Stettler, 2005).

The aims of this research were to translate and to test the reliability of the adapted version of CFQ to Brazil; to investigate parental attitudes, beliefs and practices regarding child feeding and obesity proneness in children from 2 to 11 years of age; and to assess associations between dimensions assessed by the instrument and anthropometric measurements (weight status) of both, mothers and children.

\section{Method}

\section{Participants}

The cross-sectional study included 300 mothers and 300 children of both sexes ranging from 2 to 11 years of age. This is a convenience sample, based on similar studies (Birch et al., 2001; Mulder et al., 2009; Viana et al., 2012). The pilot study 
was performed in part of the sample, comprising 30 participants, based on recommendations by Beaton, Bombardier, Guillemin, and Ferraz (2000). The participants were recruited from private schools and public health centers of Ribeirão Preto, São Paulo. Participants were voluntarily recruited to participate in the study and there were no refusals during data collection. The following items were adopted as inclusion criteria for the children sample: the absence of severe food allergies or chronic medical problems affecting food intake by the child; the absence of dietary restrictions involving animal products; the biological parents living with the child; in case of siblings, only one of the children was included in the sample. The following items were adopted as exclusion criteria for the children sample: the presence of feeding characteristics mentioned above and the presence of severe mental impairment or physical problems that prevented participation in data collection.

In order to characterize the sample concerning children, $47 \%(n=127)$ were boys and 53\% $(n=143)$ girls, ranging from 2 to 11 years old. On average, children were of normal weight according body mass index (BMI), with mean BMI of $15.9(S D=1.3)$ for boys and $16.3(S D=1.1)$ for girls. As for adults, all respondents were mothers ranging between 20 to 55 years old. On average, mothers were of normal weight, with mean BMI of $24.06(S D=.9)$. Most families indicated fathers as heads of households $(n=203,75 \%)$. Furthermore, regarding the level of education, $45.5 \%(n=123)$ of mothers had low level, and 44\% $(n=119)$ showed high level. Most fathers $(n=258,95.5 \%)$ and almost half of the mothers $(n=$ $132,48.8 \%$ ) work outside the home, reporting an average of $40 \mathrm{~h}$ per week for both cases. Regarding socioeconomic status, most families $(n=104,38.51 \%)$ were classified in class $\mathrm{C} 1$ (average family income of $\mathrm{R} \$ 1.541$ ).

\section{Instruments}

Child Feeding Questionnaire (CFQ). The CFQ is a self-report measure to assess parental beliefs, attitudes and practices regarding child feeding, with a focus on obesity proneness in children. The CFQ contains 31 items and measures seven factors: (1) Perceived responsibility (PR; three items) to assess parental responsibility perception in child feeding; (2) Perceived parent weight (PPW; four items) to assess parental own weight history perception; (3) Perceived child weight (PCW; three items) to assess parental perception concerning child's weight status history; and (4) Concern about child weight ( $\mathrm{CN}$; three items) to assess parental concern about the child risk of being overweight; (5) Restriction (RST; eight items) to assess the extent to which parents restrict their child's access to foods; (6) Pressure to eat (PE; four items) to assess parental tendency to pressure their children to eat more food, typically at mealtimes; and (7) Monitoring ( $\mathrm{MN}$; three items) to assess the extent to which parents oversee their child's eating. The acronyms refer to the initials of the names of the subscales in English. All items were measured using a 5-point Likert-type scale, having each point on the scale represented by a word anchor. To create a factor score for each of the seven factors, the mean score for the items loading on that factor was calculated. The number of items answered in the subscale PCW varies according to the age of these, it is asked to evaluate the weight over different age levels related to the years of schooling. According to the guidelines contained in the original questionnaire, the items 11,12 and 13 are not used in analysis due to sample age. Internal consistencies for the seven factors were above .70 in the English original version (Birch et al., 2001). See Table 1 for both sexes' adapted version to Brazil.

Table 1

Questionário de Alimentação da Criança (QAC) / Child Feeding Questionnaire (CFQ) (Factors: Perceived Responsibility, Perceived Parent Weight, Perceived Child Weight, Concern About Child Weight, Restriction, Pressure to Eat and Monitoring)

\begin{tabular}{|c|c|c|c|c|}
\hline Fator & Variável & Ordem & Questão & Opção de Resposta \\
\hline \multirow{3}{*}{$\begin{array}{l}\text { Percepção de } \\
\text { responsabilidade }\end{array}$} & PR1 & 1 & $\begin{array}{l}\text { Quando sua criança está em casa, com que frequência você é respon- } \\
\text { sável por alimentá-la? }\end{array}$ & \multirow{3}{*}{$\begin{array}{l}1=\text { nunca } \\
2=\text { raramente } \\
3=\text { metade do tempo } \\
4=\text { maior parte do tempo } \\
5=\text { sempre }\end{array}$} \\
\hline & PR2 & 2 & $\begin{array}{l}\text { Com qual frequência você é responsável por decidir qual é o tamanho } \\
\text { da porção de sua criança? }\end{array}$ & \\
\hline & PR3 & 3 & $\begin{array}{l}\text { Com qual frequência você é responsável por decidir se sua criança } \\
\text { come o tipo correto de comida? }\end{array}$ & \\
\hline \multirow{4}{*}{$\begin{array}{l}\text { Percepção do } \\
\text { peso dos pais }\end{array}$} & PPP1 & 4 & Sua infância (5 a 10 anos de idade). & \multirow{4}{*}{$\begin{array}{l}1=\text { muito abaixo do peso } \\
2=\text { abaixo do peso } \\
3=\text { normal } \\
4=\text { acima do peso } \\
5=\text { muito acima do peso }\end{array}$} \\
\hline & PPP2 & 5 & Sua adolescência. & \\
\hline & PPP3 & 6 & Seus 20 anos. & \\
\hline & PPP4 & 7 & Atualmente. & \\
\hline \multirow{6}{*}{$\begin{array}{l}\text { Percepção do } \\
\text { peso da criança }\end{array}$} & PPC1 & 8 & Sua criança durante o primeiro ano de vida. & \multirow{6}{*}{$\begin{array}{l}1=\text { muito abaixo do peso } \\
2=\text { abaixo do peso } \\
3=\text { normal } \\
4=\text { acima do peso } \\
5=\text { muito acima do peso }\end{array}$} \\
\hline & PPC2 & 9 & Sua criança de 1 a 2 anos. & \\
\hline & \multirow{4}{*}{ PPC3 } & 10 & Sua criança da pré-escola. & \\
\hline & & 11 & Sua criança do pré ao $3^{\circ}$ ano. & \\
\hline & & 12 & Sua criança do $4^{\circ}$ ao $6^{\circ}$ ano. & \\
\hline & & 13 & Sua criança do $7^{\circ}$ ao $9^{\circ}$ ano. & \\
\hline
\end{tabular}


...continuation

\begin{tabular}{|c|c|c|c|c|}
\hline Fator & Variável & Ordem & Questão & Opção de Resposta \\
\hline \multirow{3}{*}{$\begin{array}{l}\text { Preocupação com } \\
\text { o peso da criança }\end{array}$} & PrPC1 & 14 & $\begin{array}{l}\text { O quanto você se preocupa sobre a sua criança comer muito quando } \\
\text { você não está perto dela? }\end{array}$ & \multirow{3}{*}{$\begin{array}{l}1=\text { despreocupado } \\
2=\text { um pouco preocupado } \\
3=\text { preocupado } \\
4=\text { bem preocupado } \\
5=\text { muitopreocupado }\end{array}$} \\
\hline & PrPC2 & 15 & $\begin{array}{l}\text { O quanto você se preocupa sobre sua criança ter que fazer dieta para } \\
\text { manter um peso desejável? }\end{array}$ & \\
\hline & PrPC3 & 16 & O quanto você se preocupa sobre sua criança ficar acima do peso? & \\
\hline \multirow{8}{*}{ Restrição } & R1A & 17 & $\begin{array}{l}\text { Eu tenho que ter certeza de que minha criança não come muitos doces } \\
\text { (balas, sorvete, bolos ou tortas). }\end{array}$ & \multirow{8}{*}{$\begin{array}{l}1=\text { discordo } \\
2=\text { discordo levemente } \\
3=\text { neutro } \\
4=\text { concordo levemente } \\
5=\text { concordo }\end{array}$} \\
\hline & R1B & 18 & $\begin{array}{l}\text { Eu tenho que ter certeza de que minha criança não come muitos } \\
\text { alimentos altamente calóricos. }\end{array}$ & \\
\hline & $\mathrm{R} 1 \mathrm{C}$ & 19 & $\begin{array}{l}\text { Eu tenho que ter certeza de que minha criança não come muito de } \\
\text { seus alimentos preferidos. }\end{array}$ & \\
\hline & $\mathrm{R} 2$ & 20 & $\begin{array}{l}\text { Eu intencionalmente mantenho algumas comidas fora do alcance da } \\
\text { minha criança. }\end{array}$ & \\
\hline & $\mathrm{R} 3 \mathrm{~A}$ & 21 & $\begin{array}{l}\text { Eu ofereço doces (balas, sorvete, bolos, tortas) para a minha criança } \\
\text { como recompensa por um bom comportamento. }\end{array}$ & \\
\hline & $\mathrm{R} 3 \mathrm{~B}$ & 22 & $\begin{array}{l}\text { Eu ofereço para minha criança seu alimento preferido em troca de um } \\
\text { bom comportamento. }\end{array}$ & \\
\hline & $\mathrm{R} 4 \mathrm{~A}$ & 23 & $\begin{array}{l}\text { Se eu não orientar ou regular o que minha criança come, ela iria co- } \\
\text { mer muita porcaria. }\end{array}$ & \\
\hline & $\mathrm{R} 4 \mathrm{~B}$ & 24 & $\begin{array}{l}\text { Se eu não orientar ou regular o que minha criança come ela iria comer } \\
\text { muito de sua comida preferida. }\end{array}$ & \\
\hline \multirow{4}{*}{$\begin{array}{l}\text { Pressão para } \\
\text { comer }\end{array}$} & PC1 & 25 & Minha criança deveria sempre comer toda a comida de seu prato. & \multirow{4}{*}{$\begin{array}{l}1=\text { discordo } \\
2=\text { discordo levemente } \\
3=\text { neutro } \\
4=\text { concordo levemente } \\
5=\text { concordo }\end{array}$} \\
\hline & PC2 & 26 & $\begin{array}{l}\text { Eu tenho que ser muito cuidadoso para ter certeza de que minha } \\
\text { criança come o suficiente. }\end{array}$ & \\
\hline & PC3 & 27 & $\begin{array}{l}\text { Se minha criança diz "Eu não estou com fome", eu tento fazer ela } \\
\text { comer mesmo assim. }\end{array}$ & \\
\hline & PC4 & 28 & $\begin{array}{l}\text { Se eu não guiar ou regular o que minha criança come, ela poderia } \\
\text { comer muito menos do que deveria. }\end{array}$ & \\
\hline \multirow{3}{*}{ Monitoramento } & M & 29 & $\begin{array}{l}\text { O quanto você mantém o controle dos doces (balas, sorvetes, bolos, } \\
\text { tortas) que sua criança come? }\end{array}$ & \multirow{3}{*}{$\begin{array}{l}1=\text { nunca } \\
2=\text { raramente } \\
3=\text { às vezes } \\
4=\text { maior parte do tempo } \\
5=\text { sempre }\end{array}$} \\
\hline & M & 30 & $\begin{array}{l}\text { O quanto você mantém o controle dos lanches (batatas, salgadinhos) } \\
\text { que sua criança come? }\end{array}$ & \\
\hline & M & 31 & $\begin{array}{l}\text { O quanto você mantém o controle dos alimentos altamente calóricos } \\
\text { que sua criança come? }\end{array}$ & \\
\hline
\end{tabular}

Anthropometry. Body weight and height were the anthropometric measurements obtained in order to assess participants' nutritional status. For that reason, the following equipments were used: an electronic calibrated scale and a portable anthropometer with fixed marker for accurate reading. The Body Mass Index (BMI) was calculated through weight in kilograms divided by the square of the height in meters $\left(\mathrm{kg} / \mathrm{m}^{2}\right)$. Participant's nutritional status was defined by the BMI according to parameters recommended by the World Health Organization for adults (BMI range: $<18,5 \mathrm{~kg} / \mathrm{m}^{2}$ underweight; $18,5-24,9 \mathrm{~kg} / \mathrm{m}^{2}$ normal weight; $25-29,9 \mathrm{~kg} / \mathrm{m}^{2}$ overweight; $30-34,9 \mathrm{~kg} / \mathrm{m}^{2}$ obesity I; 35-39,9 $\mathrm{kg} / \mathrm{m}^{2}$ obesity II; $\geq 40 \mathrm{~kg} / \mathrm{m}^{2}$ obesity III) and children by percentile limits (BMI percentile range: $<3$ underweight; percentile $\geq 3$ to $<85$ normal weight; percentile $\geq 85$ to $<97$ overweight; percentile $\geq 97$ obesity; Onis et al., 2007; World Health Organization [WHO], 1995, 2000, 2006).

\section{Procedure}

Data collection. The cross-cultural adaptation process included the instrument's translation procedures and reliability test. The translation process was based on procedures suggested by World Health Organization (Beaton et al., 2000), and included the following stages: instrument translation from the source language into the target language, synthesis of translated versions, back translation, expert committee review, and test of the prefinal version. Originally in English, the CFQ was translated into target language (Brazilian Portuguese) by two native translators, informed and uninformed about the study, and two different translations were created. A synthesis version was produced by translators and researchers in order to resolve any discrepancies with translator's reports and obtain a single questionnaire version. The synthesis version was back-translated to English by two independent bilingual translators whose native language was English, who had no knowledge of the original instruments or of the assessed construct. The translations were forwarded to an expert committee composed by six experts in the field, to review all reports, reach a consensus on any discrepancy found, and develop the final version of the questionnaire for field 
testing. Then, the pretest was performed and evaluated the reliability of the instrument. The final version of CFQ was tested in a pilot study, in a small sample of 30 participants, with a 30-day interval between test and retest in order to verify the instrument's test-retest reliability.

The data collection consisted on the application of the CFQ for participants, in a sample of 270 mothers. In addition, we used the questionnaire CCEB (Portuguese abbreviation of Critério de Classificação Econômica Brasil) to assess economic characteristics of families (Associação Brasileira de Empresas de Pesquisa [ABEP], 2012). Regarding the anthropometric assessment, mothers and children's height and weight measurements were obtained by a trained staff member, according to instructions recommended by the technical rules of the Ministry of Health (Ministério da Saúde, 2011). Participants were dressed but shoes were removed before measuring.

Data analysis. For statistical analysis the IBM SPSS Statistics program (version 20.0) wasused. Weight and height data were processed with the WHO Anthro (version 3.2.2) e Anthro Plus (version 1.0.4). Data analysis was performed using descriptive statistics (mean, standard deviation, percentages, frequency, minimum, and maximum values). The test-retest reliability was analyzed using the Pearson correlation test. Cronbach's alphas were evaluated for items on each of the seven factors of the final version. Pearson correlations were used to evaluate relationships between mean item scores on each of the seven CFQ factors and children's weight status. Statistical significance levels were set at $p<.05$.

\section{Ethical Considerations}

The necessary authorization for the use of CFC was obtained from the international authors of the original instrument. This study was approved by the Institutional Ethics Committee of the Universidade de São Paulo (protocol n. 252/2006-2006.1.783.59.2 and n. 452/20092009.1.1246.59.3). When collecting the sample, permission was requested from the parents for their participation and well as the participation of their children in this study, and both were informed about the aims of the research and the voluntary nature of participation, with confidentiality and anonymity regarding the data collected guaranteed. The signed consent form was obtained from all participants.

\section{Results}

Initially, the results related to the translation and semantic equivalence of the instrument will be presented. The changes were made during the translation process on the factors, variables name and some questions. The complete translation of the questionnaire can be seen in Table 1. First, the translators and researchers opted for a single version of the instrument for both sexes, to ensure understanding by parents of girls or boys, so in all questions the word child was translated as criança. On the factors and variables name of the questionnaire, Perceived responsibility was originally translated as Percepção de Responsabilidade $(P R)$, Perceived parent weight was originally translated as Percepção do Peso dos Pais (PPP), Perceived child weight was originally translated as Percepção do Peso da Criança $(P P C)$, Concern about child weight was originally translated as Preocupação com o Peso da Criança (PrPC), Restriction was originally translated as Restrição $(R)$, Pressure to eat was originally translated as Pressão para Comer (PC), and Monitoring was originally translated as Monitoramento $(M)$. The acronyms refer to the initials of the names of the factors in Portuguese of Brazil. Regarding the Perceived child weight factor, modifications were introduced on questions9, $10,11,12$ and 13, in order to consider the age of children - attending preschool, kindergarten, elementary and middle school- and specificities of Brazilian culture. Question 9 "Your child as a toddler" was translated as "Sua criança de 1 a 2 anos". Question 10 "Your child as a pre-schooler" was translated as "Sua criança da pré-escola". Question 11 "Your child kindergarten through 2nd grade" was translated as "Sua criança do pré ao $3^{\circ}$ ano". Question 12 "Your child from 3rd through 5th grade" was translated as "Sua criança do $4^{\circ}$ ao $6^{\circ}$ ano". Question 13 "Your child from 6th through 8th grade" was translated as "Sua criança do $7^{\circ}$ ao $9^{\circ}$ ano". Regarding the Restriction factor, in the question 23 the word "junk food" initially was maintained during the translation process, but considering the Brazilian context and the need for the instrument to be used in all socioeconomic classes it was translated as porcaria, an informal term used in common and frequent vocabulary. Similarly, regarding the Monitoring factor, in the question 30 the words potato chips, Doritos, cheese puffs were translated as batatas, salgadinhos.

The Portuguese final version of the CFQ, in the current sample, had good indexes of verbal comprehension, content validity, reliability and internal consistency. Regarding the content validity, the level of agreement among experts about the contents that compose the instrument was above $80 \%$ for each question, and this accuracy rate can be considered as a criterion of adequacy. The test reliability showed a moderate and positive and significant correlation between test and retest $(r=.66, p \leq .01)$, confirming the instrument's reliability. The instrument and the subscales showed satisfactory internal consistency, with the Cronbach's alpha score higher than .70 as shown in Table 2. Cronbach's alpha for the instrument was .89 in the whole sample.

Table 2

Descriptive Statistics (Mean and Standard Deviation) and Internal Consistency Estimates for the Factors Perceived Responsibility, Perceived Parent Weight, Perceived Child Weight, Concern About Child Weight, Restriction, Pressure to Eat and Monitoring of the Child Feeding Questionnaire (CFQ)

\begin{tabular}{lccc}
\hline \multicolumn{1}{c}{ Factors } & $M(S D)$ & Range & $\alpha$ \\
\hline Perceived responsibility & $4.07(.11)$ & $1-5$ & .72 \\
Perceived parent weight & $3.10(.11)$ & $1-5$ & .81 \\
Perceived child weight & $3.05(.05)$ & $1-5$ & .80 \\
& & & \multicolumn{2}{c}{ continued... }
\end{tabular}


...continuation

\begin{tabular}{cccc}
\hline Factors & $M(S D)$ & Range & $\alpha$ \\
\hline Concern about child weight & $2.94(.22)$ & $1-5$ & .94 \\
Restriction & $3.73(.45)$ & $1-5$ & .83 \\
Pressure to eat & $3.37(.27)$ & $1-5$ & .93 \\
Monitoring & $3.94(.10)$ & $1-5$ & .90 \\
\hline
\end{tabular}

The results concerning anthropometric measurements of mothers and children are given in Table 3. It was observed that there is a prevalence of normal weight in both groups, followed by the category of overweight and obesity. The Pearson correlation analysis between the BMI data of mothers and children showed an $r=.45$ and $p \leq .01$, indicating that there was a moderate positive and significant correlation between them.

\section{Table 3}

Frequency and Percentage of Classification of Nutritional Status of Children, According to BMI-for-Age Percentile, and Mothers, According to BMI

\begin{tabular}{|c|c|c|}
\hline & \multicolumn{2}{|c|}{ Mothers $(n=270)$} \\
\hline Weight (kg) & \multicolumn{2}{|c|}{$M=62.3, S D=1.8$} \\
\hline Height $(\mathrm{cm})$ & \multicolumn{2}{|c|}{$M=160.9, S D=.8$} \\
\hline Nutritional Status & $n$ & $\%$ \\
\hline Underweight I & 8 & 3.0 \\
\hline Normal weight & 206 & 76.3 \\
\hline Overweight & 39 & 14.4 \\
\hline Obesity I & 14 & 5.2 \\
\hline Obesity II & 3 & 1.1 \\
\hline \multirow[t]{2}{*}{ Total } & 270 & 100 \\
\hline & \multicolumn{2}{|c|}{ Children $(n=270)$} \\
\hline Weight $(\mathrm{kg})$ & \multicolumn{2}{|c|}{$M=37.7, S D=1.7$} \\
\hline Height (cm) & \multicolumn{2}{|c|}{$M=153.0, S D=1.3$} \\
\hline Nutritional Status & $n$ & $\%$ \\
\hline Underweight & 12 & 4.4 \\
\hline Normal weight & 186 & 68.9 \\
\hline Overweight & 59 & 21.8 \\
\hline Obesity & 13 & 4.8 \\
\hline Total & 270 & 100 \\
\hline
\end{tabular}

Table 2 also shows the results regarding mean scores of mothers on the factors of the CFQ. On average, such results indicated, regarding the Perceived responsibility factor, that mothers considered themselves the responsible ones for feeding their child most of the time. For the Perceived parent weight factor and Perceived child weight factor, mothers reported normal weight from childhood up to the present moment for themselves and children. For the Concern about child weight factor, mothers were considered to be apprehensive. For the Restriction factor, mothers slightly agreed with the practice to restrict the intake of some types of food by their children. For the Pressure to eat factor, mothers were considered neutral about the pressure to regulate the amount of determined type of food consumed by their children. Finally, for the Monitoring factor, mothers reported that they monitor what their child eats most of the time.

Table 4 shows the results concerning the correlation test between children's nutritional status according to BMI percentile and the CFQ factors, and reveal that parents' factor scores were related to their child's weight status in predicted directions. Perceived parent weight, Perceived child weight and Restriction showed moderate positive and significant correlation with child's weight status. Concern about child weight and Monitoring showed weak positive and significant correlation with child's weight status. Pressure to eat showed weak negative and significant correlation. Perceived responsibility was not related to the child's weight status.

Table 4

Correlation Between Nutritional Status of Children, According to BMI Percentile, and the Factors of the Child Feeding Questionnaire (CFQ)

\begin{tabular}{lc}
\hline \multirow{2}{*}{ Factors } & Nutritional Status of Children $(n=270)$ \\
\cline { 2 - 3 } & $r$ \\
\hline Perceived responsibility & .11 \\
Perceived parent weight & $.40^{*}$ \\
Perceived child weight & $.61^{*}$ \\
Concern about child & $.13^{*}$ \\
weight & $.55^{*}$ \\
Restriction & $-.33^{*}$ \\
Pressure to eat & $.26^{*}$ \\
Monitoring &
\end{tabular}
$* p \leq .05$.

\section{Discussion}

The process of cultural validation of psychological measures is considered essential for comparisons between studies from different countries, languages and cultures (Borsa, Damásio, \& Bandeira, 2012; Manzi-Oliveira, Balarini, Marques, \& Pasian, 2011). During the process of translation, semantic, linguistic and contextual equivalence was obtained, and the cultural aspects of the target population were considered. The internal consistency was found to be satisfactory for almost all subscales, as well as the test-retest reliability. Similarly, the original instrument exhibited coefficients that ranged from .70 to .92 (Birch et al., 2001). The same results were found for Viana et al. (2012), which validated the CFQ in a Portuguese sample of 292 mothers and their children aged 8-12 years, alpha for the 
subscales ranged from .61 to .90 . Thus, the procedure used to establish the initial phase of cross-cultural adaptation of the instrument was found to be adequate. Further studies are needed to determine other psychometric characteristics, including through the use of confirmatory factor analysis.

In the present study, nutritional status data suggest agreement with the epidemiological results, showing normal weight prevalence among adults and children followed by an increase in overweight and obesity rates of the population (Leal et al., 2012; Ministério da Saúde, 2014). Addressing the positive correlation between children's and parental nutritional status, and considering the family setting as a major factor contributing to the development of children's eating behavior and overweight tendency in childhood, recent studies have evidenced that family adiposity patterns are well established and influenced by cultural and genetic factors (Fox et al., 2014). Therefore, there are many factors in the family setting that may affect children's eating behavior, and consequently their body weight. Among these are included the parental feeding behavior and the strategies used by the parents during child feeding (Tzou \& Chu, 2012).

Results concerning the factors of the CFQ support data from international studies that have used this instrument with the same aims (Birch et al., 2001; Camci et al., 2014; Carnell \& Wardle, 2007; Corsini et al., 2008; Geng et al., 2009; Huang et al., 2012; Kasemsup \& Reicks, 2006; Kong et al., 2015; Monnery-Patris et al., 2011; Montgomery et al., 2006; Mulder et al., 2009; Nowicka et al., 2014; O'Neill et al., 2005; Viana et al., 2012). The mean in our sample can be compared with the original research, which presented the following values in the respective factors PR $(M=3.4, S D=.95)$, PPW $(M=3.1, S D=.78), \mathrm{PCW}(M=$ $2.9, S D=.50), \mathrm{CN}(M=2.3, S D=1.15)$, RST $(M=4.0, S D$ $=.78), \mathrm{PE}(M=2.5, S D=.95)$ and $\mathrm{MN}(M=3.6, S D=.91$; Birch et al., 2001).

In this research the values of the subscales of the CFQ were studied in association with the weight status of children. The same results were found for Birch et al. (2001) in a study of two samples. Consistent with predictions, significant correlations were obtained between child's weight status (weight/height percentiles) and parents' scores on four of the factors, in the sample 1 and sample 2 respectively. Perceived parent weight $(r=.30$ and $r=.40, p \leq .001)$, perceived child weight ( $r=.43$ and $r=.50, p \leq .001)$, and concerns about child weight $(r=.46$ and $r=.35, p \leq .001)$ were positively related to the child's weight status, and pressure to eat was negatively related to child's weight status $(r=-.26, p \leq$ .001 , statistically significant only in sample 1 ). In addition, Restriction was marginally positively related to the child's weight status ( $r=.13, p \leq .01$, only in sample 1$)$; monitoring was not related to the child's weight status.

Associations between child weight status and CFQ subscale scores were of the same direction in the validation of the CFQ in Portugal. Perceived responsibility and Monitoring presented no association with BMI z scores. Pressure to Eat was inversely associated with children's weight status $(r=-.39, p \leq .001)$, which could suggest a reaction of the mothers in relation to the low weight of children. As expected, restriction is associated with children's weight status $(r=.33, p \leq .001)$, this attitude seems to translate into higher intake and is also a reaction of the mothers to the highest children's weight. All others subscales were positively associated with BMI z scores (Viana et al., 2012).

Based on this assumption, previous research identified that parents play a central role in the modulation of children's feeding behavior, being thus the ones who provide context for the child first eating experiences to an extent in which they control over the type of food offered, the portion size, mealtimes, affective contexts of feeding occasions, transmitting information about food, religion and culture, and the strategies used during child eating (Thompson, 2010). These researches show that factors of family influence evaluated through the CFQ may have effects on food acceptance patterns, the development of food preferences and the self-regulation of food intake pattern by children (Tan \& Holub, 2011; Tripicchio et al., 2014). Thus, the social context can intensify children's preferences for foods high in fat, sugar and salt or even foods low calorie and low nutritional value and, consequently, to develop a dislike for nutritious foods important for the health and growth in childhood, characterizing the effects of family setting on feeding children and on childhood obesity proneness or other diseases associated with poor eating habits (Faith, Carnell, \& Kral, 2013).

Together these findings highlight the importance of the family influence in shaping children's eating behavior and lead to the hypothesis that parental attitudes, beliefs and practices on child feeding may favor the onset of childhood obesity, as proposed by the CFQ (Birch et al., 2001). The data raised are important for implying these findings for prevention efforts. In this sense, actions of nutrition education in the family setting suggest possible areas of preventive intervention (Braden, Strong, Crow, \& Boutelle, 2015; Waters et al., 2014).

In sum, this is the first research in Brazil to use the CFQ and it was successfully translated and adapted to Portuguese in Brazil and showed good reliability. Furthermore, this questionnaire provides an appropriate tool for assessing one aspect of the family setting, parental attitudes, beliefs, and practices regarding child feeding, relevant to the development of obesity proneness in children. Considering that in Brazil there is a significant lack of available instruments that have as a purpose the evaluation to the role of the environment in the etiology of childhood overweight and obesity, the present study provided what it seems to be an excellent option of multifactorial tool for Brazilian researchers and practitioners. Thus, it can be used to design strategies for family prevention and intervention in childhood obesity.

However, because data presented here are crosssectional, they cannot speak to the causal direction of these relationships, for this we suggest longitudinal studies. Moreover, for further studies, it would be important to evaluate the relationship between the factors assessed through the instrument, obesity and demographic variables such as socioeconomic status, age and gender. 
Those relationships are already well established in the international literature, but could not be tested in the current study because of the lack of representativeness of the sample. Further studies should also offer additional support of validity and reproducibility in order to confirm the adequacy and structural invariance of the measure for different socioeconomic, age and gender groups.

\section{References}

Associação Brasileira de Empresas de Pesquisa. (2012). Critério de classificação econômica Brasil [Criteria for Economic Classification Brazil]. São Paulo, SP: ABEP.

Beaton, D. E., Bombardier, C., Guillemin, F., \& Ferraz, M. B. (2000). Guidelines for the process of cross-cultural adaptation of self-report measures. Spine, 25(24), 3186-3191.

Birch, L. L., Fisher, J. O., Grimm-Thomas, K., Markey, C. N., Sawyer, R., \& Johnson, S. L. (2001). Confirmatory factor analysis of the Child Feeding Questionnaire: A measure of parental attitudes, beliefs, and practices about child feeding and obesity proneness. Appetite, 36(3), 201-210. doi:10.1006/appe.2001.0398

Borsa, J. C., Damásio, B. F., \& Bandeira, D. R. (2012). Cross-cultural adaptation and validation of psychological instruments: Some considerations. Paidéia (Ribeirão Preto), 22(53), 423-432. doi:10.1590/S0103-863X2012000300014

Braden, A., Strong, D., Crow, S., \& Boutelle, K. (2015). Parent changes in diet, physical activity, and behavior in family-based treatment for childhood obesity. Clinical Pediatrics, 54(5), 494-497. doi:10.1177/0009922814538702

Camci, N., Bas, M., \& Buyukkaragoz, A. H. (2014). The psychometric properties of the Child Feeding Questionnaire (CFQ) in Turkey. Appetite, 78, 49-54. doi:10.1016/j.appet.2014.03.009

Carnell, S., \& Wardle, J. (2007). Associations between multiples measures of parental feedings and children's adiposity in United Kingdom preschoolers. Obesity (Silver Spring), 15(1), 137-144. doi:10.1038/ oby. 2007.513

Corsini, N., Danthiir, V., Kettler, L., \& Wilson, C. (2008). Factor structure and psychometric properties of the child feeding questionnaire in Australian preschool children. Appetite, 51(3), 474-481. doi:10.1016/j. appet.2008.02.013

Costanzo, P. R., \& Woody, E. Z. (1985). Domainspecific parenting styles and their impact on the child's development of particular deviance: The example of obesity proneness. Journal of Social and Clinical Psychology, 3(4), 425-445. doi:10.1521/jscp.1985.3.4.425
Faith, M. S., Carnell, S., \& Kral, T. V. E. (2013). Genetics of food intake self-regulation in childhood: Literature review and research opportunities. Human Heredity, 75(2-4), 80-89. doi:10.1159/000353879

Fox, C. S., Pencina, M. J., Heard-Costa, N. L., Shrader, P., Jaquish, C., O’Donnell, C. J., . . . D'Agostinho, R. B. (2014). Trends in the association of parental history of obesity over 60 years. Obesity (Silver Spring), 22(3), 919-924. doi:10.1002/oby.20564

Geng, G., Zhu, Z., Suzuki, K., Tanaka, T., Ando, D., Sato, M., \& Yamagata, Z. (2009). Confirmatory factor analysis of the Child Feeding Questionnaire (CFQ) in Japanese elementary school children. Appetite, 52(1), 8-14. doi:10.1016/j.appet.2008.06.015

Giskes, K., van Lenthe, F., Avendano-Pabon, M., \& Brug, J. (2010). A systematic review of environmental factors and obesogenic dietary intakes among adults: Are we getting closer to understanding obesogenic environments? Obesity Reviews, 12(5), e95-e106. doi:10.1111/j.1467-789X.2010.00769.X

Huang, S. H., Parks, E. P., Kumanyika, S. K., Grier, S. A, Shults, J., Stallings, V. A., \& Stettler, N. (2012). Child-feeding practices among Chinese-American and non-Hispanic white caregivers. Appetite, 58(3), 922927. doi:10.1016/j.appet.2012.02.008

Instituto Brasileiro de Geografia e Estatística. (2010). Pesquisa de Orçamentos Familiares 2008-2009: Antropometria e estado nutricional de crianças, adolescentes e adultos no Brasil [Household Budget Survey 2008-2009: Anthropometric and nutritional status of children, adolescents and adults in Brazil]. Rio de Janeiro, RJ: IBGE.

Johnson, S. L., \& Birch, L. L. (1994). Parents' and children's adiposity and eating style. Pediatrics, 94(5), 653-661. Retrieved from http://pediatrics.aappublications.org/ content/pediatrics/94/5/653.full.pdf

Kasemsup, R., \& Reicks, M. (2006). The relationship between maternal child-feeding practices and overweight in Hmong preschool children. Ethnicity \& Disease, 16(1), 187-193.

Kong, A., Vijayasiri, G., Fitzgibbon, M. L., Schiffer, L. A., \& Campbell, R. T. (2015). Confirmatory factor analysis and measurement invariance of the Child Feeding Questionnaire in low-income Hispanic and AfricanAmerican mothers with preschool-age children. Appetite, 90, 16-22. doi:10.1016/j.appet.2015.02.027

Leal, V. S., Lira, P. I. C., Menezes, R. C. E., Oliveira, J. S., Costa, E. C., \& Andrade, S. L. L. S. (2012). Desnutrição e excesso de peso em crianças e adolescentes: Uma revisão de estudos brasileiros [Malnutrition and excess weight in children and adolescents: A review of Brazilian studies]. Revista Paulista de Pediatria, 30(3), 415-422. doi:10.1590/S0103-05822012000300017 
Manzi-Oliveira, A. B., Balarini, F. B., Marques, L. A. S., \& Pasian, S. R. (2011). Adaptação transcultural de instrumentos de avaliação psicológica: Levantamento dos estudos realizados no Brasil de 2000 a 2010 [Crosscultural adaptation of psychological assessment instruments: Brazilian literature review from 2000 to 2010]. Psico-USF, 16(3), 367-381. doi:10.1590/ S1413-82712011000300013

Ministério da Saúde. Secretaria de Atenção à Saúde. Departamento de Atenção Básica. (2011). Orientações para coleta de análise de dados antropométricos em serviços de saúde: Norma Técnica do Sistema de VigilânciaAlimentareNutricional-SISVAN [Guidelines for collection and analysis of anthropometric data in health services: Technical standard system of food and nutrition surveillance - SISVAN] (Série G, Estatística e Informação em Saúde). Brasília, DF: Ministério da Saúde.

Ministério da Saúde. Secretaria de Vigilância em Saúde. Departamento de Vigilância de Doenças e Agravos não Transmissíveis e Promoção da Saúde. (2014). Vigitel Brasil 2013: Vigilância de fatores de risco e proteção para doenças crônicas por inquérito telefônico [Vigitel Brazil 2013: Protective and risk factors for chronic diseases by telephone survey]. Brasília, DF: Ministério da Saúde.

Monnery-Patris, S., Rigal, N., Chabanet, C., Boggio, V., Lange, C., Cassuto, D. A., \& Issanchou, S. (2011). Parental practices perceived by children using a French version of the Kids' Child Feeding Questionnaire. Appetite, 57(1), 161-166. doi:10.1016/j. appet.2011.04.014

Montgomery, C., Jackson, D. M., Kelly, L. A., \& Reilly, J. J. (2006). Parental feeding style, energy intake and weight status in young Scottish children. British Journal of Nutrition, 96(6), 1149-1153. doi:10.1017/ BJN20061968

Mulder, C., Kain, J., Uauy, R., \& Seidell, J. C. (2009). Maternal attitudes and child-feeding practices: Relationship with the BMI of Chilean children. Nutrition Journal, 8, 37. doi:10.1186/1475-2891-8-37

Nowicka, P., Sorjonen, K., Pietrobelli, A., Flodmark, C. E., \& Faith, M. S. (2014). Parental feeding practices and associations with child weight status. Swedish validation of the Child Feeding Questionnaire finds parents of 4-year-olds less restrictive. Appetite, 81, 232-241. doi:10.1016/j.appet.2014.06.027

O’Neill, K. L., Shults, J., Stallings, V. A., \& Stettler, N. (2005). Child feeding practices in children with Down syndrome and their siblings. The Journal of Pediatrics, 146(2), 234-238. doi:10.1016/j.jeds.2004.10.045

Onis, M., Onyango, A. W., Borghi, E., Siyam, A., Nishida, C., \& Siekmann, J. (2007). Development of a WHO growth reference for school-aged children and adolescents. Bulletin of the World Health Organization, 85(9), 660-667. doi:10.2471/BLT.07.043497
Popkin, B. M., Adair, L. S., \& Ng, S. W. (2012). Global nutrition transition and the pandemic of obesity in developing countries. Nutrition Reviews, 70(1), 3-21. doi:10.1111/j.1753-4887.2011.00456.x

Quaioti, T. C. B., \& Almeida, S. S. (2006). Determinantes psicobiológicos do comportamento alimentar: Uma ênfase em fatores ambientais que contribuem para a obesidade [Psychobiological determinants of food behavior: An emphasis on environmental factors contributing to obesity]. Psicologia USP, 17(4), 193211. doi:10.1590/S0103-65642006000400011

Scaglioni, S., Arrizza, C., Vecchi, F., \& Tedeschi, S. (2011). Determinants of children's eating behavior. The American Journal of Clinical Nutrition, 94(6 Suppl), 2006S-2011S. doi:10.3945/ajen.110.001685

Tan, C. C., \& Holub, S. C. (2011). Children's selfregulation in eating: Associations with inhibitory control and parent's feeding behavior. Journal of Pediatric Psychology, 36(3), 340-345. doi:10.1093/ jpepsy/jsqo89

Thompson, M. E. (2010). Parental feeding and childhood obesity in preschool-age children: Recent findings from the literature. Issues in Comprehensive Pediatric Nursing, 33(4), 205-267. doi:10.3109/01460862.2010 .530057

Tripicchio, G. L., Keller, K. L., Johnson, C., Pietrobelli, A., Heo, M., \& Faith, M. S. (2014). Differential maternal feeding practices, eating self-regulation, and adiposity in young twins. Pediatrics, 134(5), e1399-e1404. doi:10.1542/peds.2013-3828

Tzou, I. L., \& Chu, N.-F. (2012). Parental influence on childhood obesity: A review. Health, 4(12A), 14641470. doi:10.4236/health.2012.412A211

Viana, V., Franco, T., Morais, C., Almeida, P., Silva, D., \& Guerra, A. (2012). Controlo alimentar materno e estado ponderal: Resultados do Questionário Alimentar para Crianças [Mother's feeding control and weight status: Results of the Child Feeding Questionnaire]. Psicologia, Saúde \& Doenças, 13(2), 298-310. Retrieved from http://www.scielo.gpeari.mctes.pt/pdf/ $\mathrm{psd} / \mathrm{v} 13 \mathrm{n} 2 / \mathrm{v} 13 \mathrm{n} 2 \mathrm{a} 12 . \mathrm{pdf}$

Waters, E., Silva-Sanigorski, A., Hall, B. J., Brown, T., Campbell, K. J., Gao, Y., . . . Summerbell, C. D. (2011). Interventions for preventing obesity in children. Cochrane Database of Systematic Reviews, 12, CD001871. doi:10.1002/14651858.CD001871. pub3

World Health Organization. (1995). Infants and children. In Physical status: The use and interpretation of anthropometry: Report of a WHO Expert Committee (Technical Report Series, No. 854, pp. 161-262). Geneva, Switzerland: WHO.

World Health Organization. (2000). Obesity: Preventing and managing the global epidemic: Report of a WHO consultation. (Technical Report Series, No. 894). Geneva, Switzerland: WHO. 
World Health Organization. (2006). WHO child growth standards: Length/height-for-age, weight-for-age, weight-for-length, weight for-height and body mass index-for-age: Methods and development. Geneva, Switzerland: WHO. Retrieved from http://www.who. int/childgrowth/standards/Technical_report.pdf?ua $=1$

Luciana Lorenzato holds a MSc by the Universidade de São Paulo.

Isadora Silva Miranda Cruz holds a MSc by the Universidade de São Paulo.

Telma Maria Braga Costa is a Full Professor of the Universidade de Ribeirão Preto.

Sebastião Sousa Almeida is a Full Professor of the Universidade de São Paulo.

Received: May 20, 2015

1st Revision: Nov. 3, 2015

2nd Revision: Feb. 15, 2016

Approved: Feb. 23, 2016

How to cite this article:

Lorenzato, L., Cruz, I. S. M., Braga Costa, T. M., \& Almeida, S. S. (2017). Translation and cross-cultural adaptation of a Brazilian version of the Child Feeding Questionnaire. Paidéia (Ribeirão Preto), 27(66), 33-42. doi: 10.1590/1982-43272766201705 